\title{
Effect of Organic Manures on the Growth of Wheat (Triticum aestivum) and Soil Enzymatic Activity
}

\author{
Prerna B. Jetpariya and Sana A. Kalyani* \\ Shree P.M. Patel Institute of P.G. Studies and Research in Science, Anand, Gujarat, India \\ *Corresponding author
}

\section{A B S T R A C T}

\section{Keywords}

NPK (Nitrogen, Phosphorus, Potassium), Vermicompost, Farmyard manure, Paddy husk, dehydrogenase, urease, acid phosphatase

Article Info

Accepted: 20 June 2021 Available Online: 10 July 2021
Organic agriculture is a holistic production management system which promotes and enhances ecosystem health, including biological cycles and soil biological activity. Application of different organic manures in combination with inorganic fertilizers to wheat crop might give a substitute under pot condition. A pot experiment is conducted during 2012-13with the objective to find out best combination and type of organic and inorganic fertilizer for wheat (Triticum aestivum) production. The experiment was laid out with three replication. The treatments were: control (T1, NPK), 100+60+40 NPK $\mathrm{Kg} / \mathrm{ha}+5$ ton/ha Farmyard manure (T2), $100+60+40$ NPK $\mathrm{Kg} / \mathrm{ha}+5$ ton/ha Vermicompost (T3), 100+60+40 NPK Kg/ha+5ton/ha Paddy husk (T4), 100+60+40 NPK Kg/ha+2.5 ton/ha Farmyard manure+2.5 ton/ha Vermicompost (T5). After 60days spike length $(\mathrm{cm})$, root length $(\mathrm{cm})$ and number of spikelet's recorded. The soil enzymes dehydrogenase, urease, acid and alkaline phosphatase activity were measured. Enzyme activity in soil is regulated by $\mathrm{pH}$ and microbial biomass, which is correlate to soil organic manures content, as well as to soil compaction. The laboratory experiment is conducted in order to monitor the decomposition of vermicompost, paddy husk and farmyard manure when applied in soil under field condition. The rate of decomposition of organic manures was determined in terms of $\mathrm{mg}$ of $\mathrm{CO}_{2}$ evolution per $100 \mathrm{~g}$ of soil.

\section{Introduction}

Worldwide, interest in the use of organic manure is increasing day by day due to depletion in the soil fertility. Continuous use of inorganic fertilizers potential pollutes the environment (Oad et al., 2004). Synthesis of chemical fertilizers consumes a large amount of energy and money. However, the integration of organic sources and synthetic sources of nutrients not only supply essential nutrients but also have some positive interactions leading to increase efficiency and thereby, reduce environmental hazards (Ahmad et al., 1996). The first step should be to increase the organic matter content of the soils through incorporation of as much crop stubble as possible, addition of various kinds 
of composts, inclusion of rotation crops that contribute organic matter through dropped leaves, and use of legumes as green manures.

Soil is usually degraded due to the constant use and the need to be replenished either by the use of organic matter or fertilizer (Yadav and Arora, 2018). Soil microbes decompose the organic materials to obtain energy for growth and carbon for the synthesis of new cell material. Carbon dioxide, methane, organic acids, alcohol and other oxidised and partially oxidized form of $\mathrm{C}$ may be metabolic wastes for one group of microbes, whereas they may serve as energy and $\mathrm{C}$ Source for other group. Enzymes are released in the process of decomposition. Possible indicator value of the microbial parameters for environmental stress in general had investigated through microbial possessions including biomass and soil enzyme processes (Bandick et al., 1999). Enzyme activity in soil is regulated by $\mathrm{pH}$ and microbial biomass (Dick et al., 1988), which is correlate to soil organic as to soil moisture content (Harrison,1983) as well as to soil compaction (Karaca et al., 2000). Soil enzyme activity is variable in time and limited by available substrate supply (Degens et al., 1988) and may provide useful linkage between microbial community composition and carbon processing (Waldrop et al., 2000). Enzymatic activities as caused by soil microbial activities were sensitive indicators to detect changes occurring in soils (Gonzalez et al., 2007).

Wheat (Triticum aestivum) is grown all over the world for its high nutritious value. It is ranked among the top three most produced cereal crops in the world, along with corn and rice (Byerlee et al., 1983). Wheat grain is consumed in several ways in a number of industries and commercial products. Optimal crop growth requires a non-limiting supply of resources such as water and nutrient (Reynolds et al., 1998; Midmore et al., 1984).
The application of organic manures like vermicompost, paddy husk and farmyard manure to soil have increased crop yield, improved soil fertility, increased soil organic matter, increased microbial activities and improved soil structure for sustainable agriculture for further years (Blair et al., 2005; Kundu et al., 2006). However the proper combination of both organic and inorganic fertilizers have better effects on crop growth and development and yield component of wheat than alone (Budaruddin et al., 1999; Hossain et al., 2002; Manna et al., 2005).

Hence in light of the significance of the above informatics and possibilities, research project entitled "Effect of organic manures with recommended dose of NPK on the performance of Wheat (Triticum aestivum)" was undertaken with the objectives: to understand the effect of organic manures on growth and physiological changes during the growth of wheat (Triticum aestivum); and soil bio-chemical properties including soil enzymatic activity, in comparison with chemical fertilizer NPK; and to understand the decomposition rate of organic manures on soil.

\section{Materials and Methods}

\section{Study area}

The study was conducted in the Shree P. M. Patel Institute of Post Graduate Studies And Research In science, Anand (located at $22^{\circ} 32^{\prime}$ $\mathrm{N}$ Latitude $73^{\circ} 00^{\prime} \mathrm{E}$ Longitude). The climate condition is hot and dry, pre-monsoon summer months May to June followed by monsoon period June to September. The subsequent short period of October to November received uncertain and infrequent showers followed by fair, dry and mild winter December to February. The mean air temperatures are about $40^{\circ} \mathrm{C}$ during April-May and minimum, 15-20 $\mathrm{C}$ noticed during December-January. Bulk of 
the rainfall is received during July to September months and the mean annual rainfall. The soil used in this study was collected from farmer's field at Anand, Gujarat, India, during the winter season of 2012-2013.

\section{Pot experiment}

To know the response of different organic manures on the wheat (Triticum aestivum) and also to monitor effect of manures on soil biochemical changes, microbial population and enzymatic activity a pot experiment was conducted. Polythene pots of approximately of $3 \mathrm{Kg}$ capacity were filled with finely powdered and sieved soil. The different organic manure treatments were given along with NPK fertilizer. The treatments imposed were T1: NPK (Control); T2: NPK and vermicompost; T3: NPK and farm yard manure; T4: NPK and paddy husk; T5: NPK and $1 / 2$ farm yard manure and $1 / 2$ vermicompost. Each treatment was replicated three times in a completely randomized block design. Pots were arranged on a floor in a wire-netting greenhouse under natural environmental conditions. Water was added to all the pots to bring the soil to $100 \%$ saturation and allowed to equilibrate.

\section{Laboratory experiment}

In order to monitor the decomposition of Vermicompost, paddy husk and farmyard manure when applied in soil under field capacity moisture condition laboratory incubation experiment was initiated $100 \mathrm{~g}$ soil treated with Vermicompost, Paddy husk and farmyard manure at 5 ton ha ${ }^{-1}$ were mixed and transferred to $500 \mathrm{ml}$ capacity. The glass tube containing $10 \mathrm{ml}$ of $0.5 \mathrm{~N} \mathrm{NaOH}$ was hung in each flask and stoppered and made air tight with paraffin wax. The flasks were incubated at $27 \pm 5^{\circ} \mathrm{c}$ for 60 days. All the flasks were replicated thrice. A control containing only soil and a blank were also maintained. Rate of decomposition was determined in terms of $\mathrm{mg}$ of $\mathrm{CO}_{2}$ evolution per $100 \mathrm{~g}$ of soil (Pramer and Schmidt, 1964).

\section{Determination of soil acid and alkaline phosphatase activity}

$3 \mathrm{ml}$ of substrate incubated at $37^{\circ} \mathrm{C}$ for 5 minutes. Then $0.5 \mathrm{ml}$ of enzyme extract added and mixed well. $0.5 \mathrm{ml}$ from this mixture removed immediately and mixed it with $9.5 \mathrm{ml}$ $0.085 \mathrm{~N} \mathrm{NaOH}$. This corresponds to zero time assay (blank). Then remaining solution (Substrate + enzyme) incubated for $15 \mathrm{~min}$ at $37^{\circ} \mathrm{C}$. Then $0.5 \mathrm{ml}$ sample drawn from this and mixed it with $9.5 \mathrm{ml} \mathrm{NaOH}$ solution. The absorbance of blank measured at $405 \mathrm{~nm}$. 0.2 to $1.0 \mathrm{ml}$ (4 to $20 \mathrm{mM}$ ) of aliquot taken for standard, diluted to $10 \mathrm{ml}$ with $\mathrm{NaOH}$ solution. Acid phosphatase enzyme was extracted in citrate buffer ( $\mathrm{pH}-5.2)$. Alkaline phosphatase enzyme was extracted in glycine- $\mathrm{NaOH}$ buffer(pH-10.4) (Tabatabi M A, Bremmer J M,1969).

\section{Determination of soil Urease activity}

\section{Method of Enzyme Extraction}

$10 \mathrm{~g}$ of dry and sieved soil was taken and 1.5 $\mathrm{ml}$ of toluene added. Mixed well and incubated for 15 minutes. Then $10 \mathrm{ml}$ of urea solution and $20 \mathrm{ml}$ of citrate buffer added. Mixed thoroughly and incubated for 3 hours at $37 \mathrm{C}$ in an incubator. The solution diluted to $100 \mathrm{ml}$ with water. Filtered through a fluted paper \& filtrate used as enzyme source. For each soil sample, blank was prepared, similarly containing water instead of water solution through above steps.

\section{Enzyme assay}

For enzyme assay $1 \mathrm{ml}$ of filtrate, $9 \mathrm{ml}$ of water, $4 \mathrm{ml}$ phenate solution $\& 3 \mathrm{ml}$ of sodium 
hypochlorite solution taken into $50 \mathrm{ml}$ volumetric flask. Mixed well \& allowed standing for 20 min until the maximum color was obtained. Diluted to $50 \mathrm{ml}$ with water and mixed well. Reading was taken at $630 \mathrm{~nm}$ within 60 minute against reagent. The standard curve constructed by pipetting out 0 , $1,2,4,6,8$ and $1 \mathrm{ml}$ of diluted standard ammonium sulphate solution into a series of $50 \mathrm{ml}$ volumetric flasks and volume made in each flask to $10 \mathrm{ml}$ with water. Then $4 \mathrm{ml}$ of phenate solution and $3 \mathrm{ml}$ of $\mathrm{NaOCl}$ solution added and proceed as for sample solution. The absorbance measured against the blank i.e. zero flask \& plot a graph optical density v/s concentration.

\section{Determination of soil dehydrogenase Activity}

One gram of air dried soil sample taken in airtight screw capped test tube (15 ml capacity). Then $0.2 \mathrm{ml}$ of $3 \%$ TTC $(2,3,5-$ Triphenyltetrazolium chloride) and $0.5 \mathrm{ml} 15$ glucose solution taken in each tube. All tubes incubated at $28 \pm 0.5{ }^{0} \mathrm{C}$ for $24 \mathrm{~h}$. After incubation, $10 \mathrm{ml}$ of methanol added. The solution was shaken vigorously and allowed to stand for $6 \mathrm{~h}$. The clear pink coloured supernatant withdrawn and reading taken with a spectrophotometer at a wave length of $485 \mathrm{~nm}$ (blue filter).

\section{Results and Discussion}

The effect of different organic manures on wheat along with inorganic fertilizers on growth and development, yield and yield attributes and change in soil characteristics in wheat harvest in pot culture experiments are discussed.

\section{The plant growth parameters}

The plant shoot length was maximum in control as compared to other manorial treatments after first harvesting, because at initial stage decomposition of organic manures was slow. After second harvesting higher shoot length was observed in vermicompost, farmyard manure and paddy husk along with NPK as compared to control. After third harvesting higher shoot length was also recorded in all manorial treatments as compared to control. It was because of decomposition of organic manures reached at its peak gave nutrients to plant for better growth. Organic matter from manure, besides supplying multiple nutrients to the soil, affects soil organic matter and tilth in favour of crop emergence and growth (Schoenau et al., 2000; Assefa, 2002; Campbell et al., 1986; Hoyt and Rice, 1977; Stewart, 1982; Unger and Stewart, 1974; Meek et al., 1982; Allison, 1973).The effect of these different organic fertilizers showed significant increase of the biomass of wheat in all the treatments in comparison to controlled one. Plant's response to vermicompost showed much better result than any other manorial treatments (Gautam Kumar et al., 2010).

The number of grains was found to be higher in vermicompost, farmyard manure and paddy husk given in combination with NPK after second harvesting, because of regular availability of nutrients to plants due to decomposition of vermicompost, farmyard manure and paddy husk in soil.

The maximum grain yield was recorded in paddy husk along with NPK after third harvesting, because of slow release of nutrients due to decomposition of paddy husk attained 36 days after incorporation (fig.). The higher spike length was recorded in vermicompost, farmyard manure and paddy husk along with NPK after second and third harvesting as compared to control, decomposition of organic manures releases $\mathrm{N}$ sources had significant effect on spike length. Results showed that either mineral $\mathrm{N}$ or 
organic $\mathrm{N}$ both helped the plants to produce well developed spikes (Khan et al., 1996, Singh et al., 2001, Iqbal et al., 2002).

Decomposition rate of Vermicompost, farmyard manure and paddy husk

The study from graph of decomposition of organic manures suggests that the decomposition of vermicompost evolved 114 mg $\mathrm{CO}_{2}$ attained very early 22 days after incorporation. However, decomposition of farm yard manure and paddy husk evolved 112.4 and $101.3 \mathrm{mg} \mathrm{CO}_{2}$ attained 28 and 36 days respectively, after incorporation. Interestingly it was observed that only after 22 days the decomposition in the form of $\mathrm{CO}_{2}$ evolution started to increase to peak in case of vermicompost treated soil. In case of farmyard manure treated soil, decomposition was attained to optimum at 28 days after incorporation. However, in paddy husk treated soil, decomposition was attained to optimum at 36 days after incorporation. This shows that decomposition of paddy husk is slow initially and it takes about 36 days to gets decompose and supply nutrients to treated soils. These results also showed that decomposition of all three organic manures decreases gradually after 61 days after incorporation. This results suggests that vermicompost, paddy husk and farmyard manure if applied, should be incorporated in soil well in advance before sowing to enable the plants get nutrient supply from the since day initial stages (Naher et al., 2004).

\section{Acid phosphatase activity}

In first sampling the maximum acid phosphatase activity was recorded as $9.46 \mu \mathrm{g}$ $\mathrm{PNP} / \mathrm{g}$ in NPK $+1 / 2$ vermicompost $+1 / 2$ farmyard manure and minimum activity was observed $8.54 \mu \mathrm{g} \mathrm{PNP/g}$ in soil treated with NPK + vermicompost. In second sampling the maximum acid phosphatase activity was recorded as $10.81 \mu \mathrm{g} \mathrm{PNP/g}$ in $\mathrm{NPK}+$ vermicompost and minimum activity was observed $10.16 \mu \mathrm{g} \mathrm{PNP} / \mathrm{g}$ in soil treated with NPK $+1 / 2$ vermicompost $+1 / 2$ farmyard manure. In third sampling the maximum acid phosphatase activity was recorded as $7.1 \mu \mathrm{g}$ $\mathrm{PNP} / \mathrm{g}$ in NPK+ vermicompost and minimum activity was observed $5.5 \mu \mathrm{g} \mathrm{PNP/g}$ in soil treated with control.

\section{Alkaline phosphatase activity}

In first sampling the maximum alkaline phosphatase activity was recorded as $10.63 \mu \mathrm{g}$ $\mathrm{PNP} / \mathrm{g}$ in NPK+ paddy husk and minimum activity was observed $9.2 \mu \mathrm{g} \mathrm{PNP/g}$ in soil treated with NPK + vermicompost. In second sampling the maximum alkaline phosphatase activity was recorded as $13.07 \mu \mathrm{g} \mathrm{PNP} / \mathrm{g}$ in $\mathrm{NPK}+$ vermicompost and minimum activity was observed $11.56 \mu \mathrm{g} \mathrm{PNP/g}$ in soil treated with control. In third sampling the maximum alkaline phosphatase activity was recorded as7.53 $\mu \mathrm{g} \mathrm{PNP/g}$ in NPK+ vermicompost and minimum activity was observed $6.23 \mu \mathrm{g}$ $\mathrm{PNP} / \mathrm{g}$ in soil treated with control.

Phosphatases are a broad group of enzymes that are capable of catalysing hydrolysis of esters and anhydrides of phosphoric acid (Schmidt and Lawoski, 1961). Both acid and alkaline phosphatases activity was lower in the first and third harvesting stage while it showed higher during second harvesting stages in all the treatments. The soil phosphatase activity depends on soil $\mathrm{pH}$ values.

\section{Urease activity}

In first sampling the maximum urease activity was recorded as $13.23 \mu \mathrm{g} / \mathrm{NH}_{4}$ in NPK+ farmyard manure and minimum activity was observed $9.36 \mu \mathrm{g} / \mathrm{NH}_{4}$ in soil treated with NPK + vermicompost. 
Table.1 Physico - chemical properties of the Initial soil

\begin{tabular}{|c|c|}
\hline Particular & Values \\
\hline $\begin{array}{l}\text { 1. Mechanical analysis } \\
\text { Bulk density }\left(\mathrm{Mg} \mathrm{m}^{-3}\right)\end{array}$ & 1.40 \\
\hline 2. Bio-chemical analysis & \\
\hline Soil pH (1:2) & 7.61 \\
\hline Electrical conductivity $\left(\mathrm{dS} \mathrm{m}^{-1}\right)(1: 2)$ & 1.40 \\
\hline Moisture content (\%) & 2.73 \\
\hline Organic carbon $(\%)$ & 0.38 \\
\hline Available phosphate $\left(\mathrm{mg} \mathrm{kg}^{-1}\right)$ & 11.2 \\
\hline Available potassium $\left(\mathrm{kg} \mathrm{K}_{2} \mathrm{O} \mathrm{ha}^{-1}\right)$ & low below 112 \\
\hline Ammonical N (mg kg $\left.{ }^{-1}\right)$ & low about-15 \\
\hline Nitrate $\mathbf{N}\left(\mathrm{mg} \mathrm{kg}^{-1}\right)$ & very-low-04 \\
\hline Total carbon $\left(\mathrm{g} \mathrm{kg}^{-1}\right)$ & 7 \\
\hline Total nitrogen $\left(\mathrm{g} \mathrm{kg}^{-1}\right)$ & 0.039 \\
\hline $\mathrm{C}: \mathrm{N}$ & 179.48 \\
\hline Urease $\left(\mu \mathrm{g} \mathrm{NH}_{3}-\mathrm{N} \mathrm{g}^{-1} h^{-1}\right)$ & 3.83 \\
\hline Acid phosphatase ( $\mu \mathrm{g}$ PNP $\left.\mathrm{g}^{-1} \mathrm{~h}^{-1}\right)$ & 4.54 \\
\hline Alkaline phosphatase ( $\mu \mathrm{g}$ PNP $\left.\mathrm{g}^{-1} h^{-1}\right)$ & 4.54 \\
\hline Dehydrogenase ( $\mu \mathrm{g}$ TPF $\left.\mathrm{g}^{-1} \mathrm{~h}^{-1}\right)$ & 5.64 \\
\hline
\end{tabular}

Table.2 Chemical characteristics of organic manures

\begin{tabular}{|c|c|c|c|}
\hline Parameters & Vermicompost & Farmyard manure & Paddy husk \\
\hline pH (1:5) & 6.69 & 7.04 & 6.89 \\
\hline $\begin{array}{l}\text { Electrical conductivity (1:5) } \\
\left(\mathrm{dS} \mathrm{m}^{-1}\right)\end{array}$ & 2.5 & 0.7 & 1.8 \\
\hline Total phosphate $\left(\mathrm{mg} \mathrm{kg}^{-1}\right)$ & 284 & 224 & 384 \\
\hline Total potassium (mg kg $\left.{ }^{-1}\right)$ & 392 & 315 & 345 \\
\hline Total N $\left(\mathrm{g} \mathrm{kg}^{-1}\right)$ & 14.7 & 10.4 & 6.93 \\
\hline Total C $\left(\mathrm{g} \mathrm{kg}^{-1}\right)$ & 270 & 230 & 357 \\
\hline $\mathrm{C}: \mathrm{N}$ & 18.3:1 & 22.1:1 & 51.5:1 \\
\hline Moisture content (\%) & 56.60 & 23.40 & 7.29 \\
\hline
\end{tabular}

Table.3 Chemical parameters of irrigation water

\begin{tabular}{|c|c|}
\hline Parameter & Value \\
\hline pH & $\mathbf{8 . 2 6}$ \\
\hline EC $(\mathbf{d S} / \mathbf{m})$ & $\mathbf{0 . 7 0}$ \\
\hline $\mathrm{Na}$ & $\mathbf{5 8 . 7 5}$ \\
\hline $\mathrm{K}$ & $\mathbf{0 . 0 8}$ \\
\hline $\mathrm{Ca}$ & Traces \\
\hline $\mathrm{Mg}(\mathbf{m e q} / \mathbf{l})$ & $\mathbf{7 . 0}$ \\
\hline $\mathrm{Cl}(\mathbf{m e q} / \mathbf{l})$ & $\mathbf{3 0 . 0}$ \\
\hline $\mathrm{HCO}_{3}(\mathbf{m e q} / \mathbf{l})$ & 15 \\
\hline $\mathrm{CO}_{3}(\mathbf{m e q} / \mathbf{l})$ & 10 \\
\hline
\end{tabular}


Fig.1 Decomposition rate of Vermicompost, farmyard manure and paddy husk

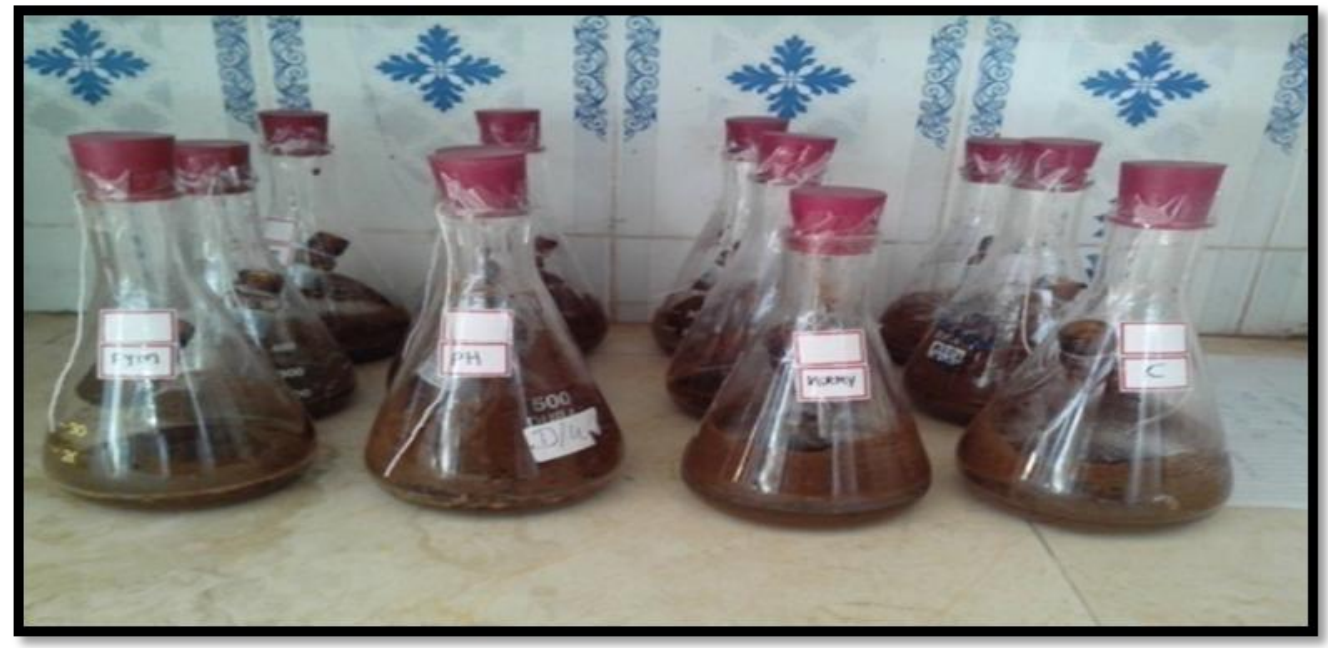

Fig.2 Decomposition of organic manures in soil

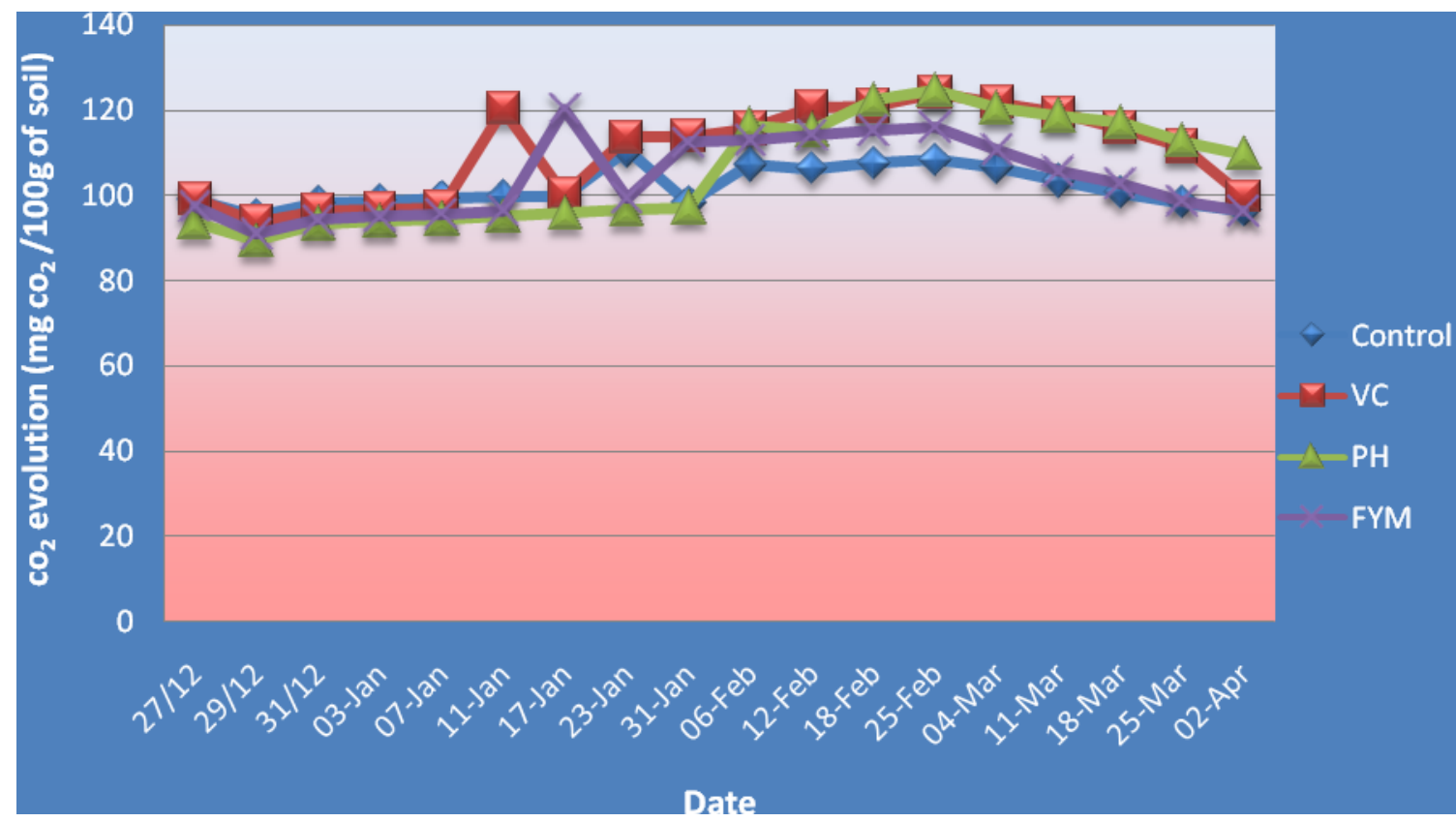


Fig.3 Effect of organic manures on soil acid phosphatase activity

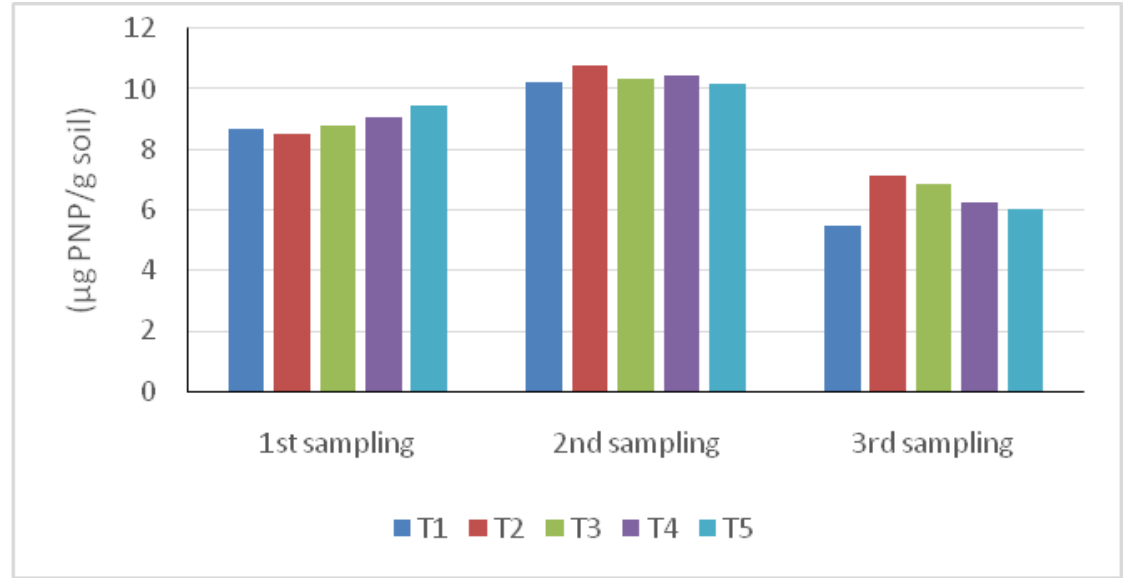

Fig.4 Effect of organic manures on soil alkaline phosphatase activity

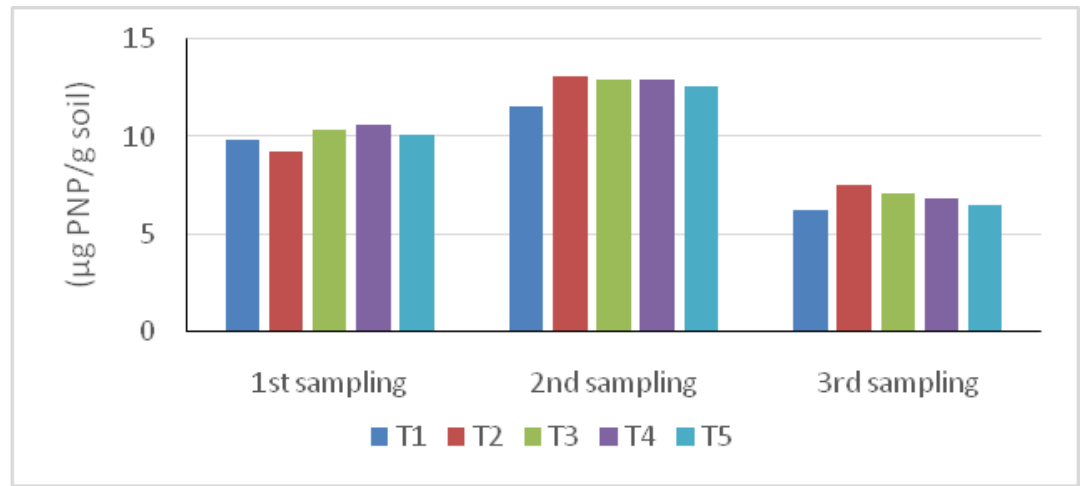

Fig.5 Effect of organic manures on soil urease activity

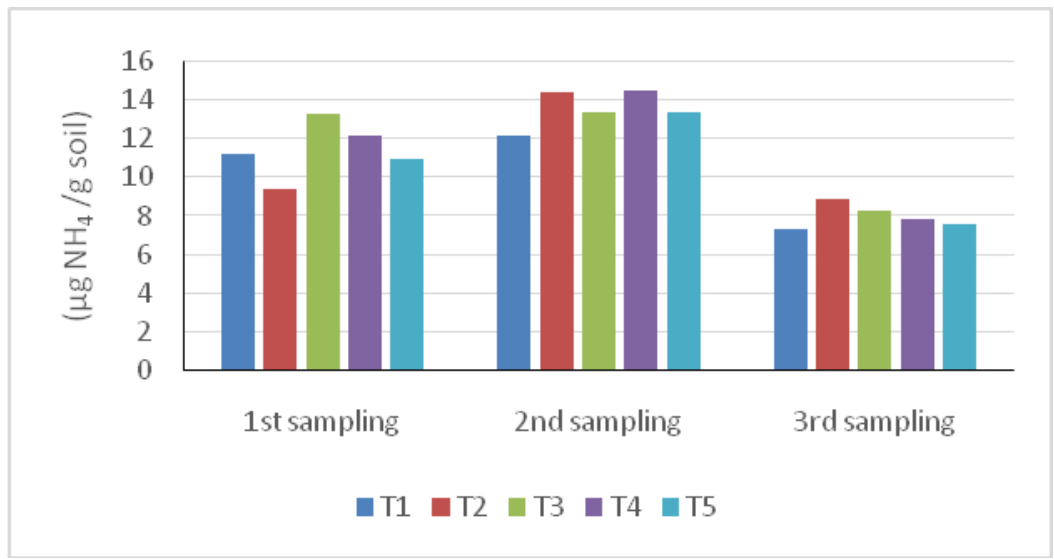


Fig.6 Effect of organic manures on soil dehydrogenase activity

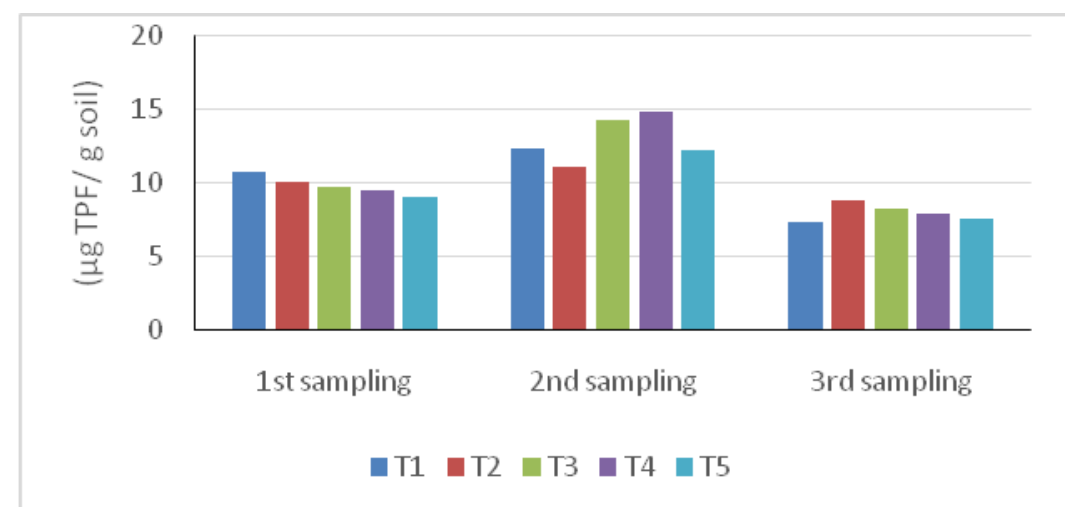

In second sampling the maximum urease activity was recorded as $14.49 \mu \mathrm{g} / \mathrm{NH}_{4}$ in $\mathrm{NPK}+$ paddy husk and minimum activity was observed $12.17 \mu \mathrm{g} / \mathrm{NH}_{4}$ in soil treated with control. In third sampling the maximum urease activity was recorded as $8.83 \mu \mathrm{g} / \mathrm{NH}_{4}$ in NPK+ vermicompost and minimum activity was observed $7.3 \mu \mathrm{g} / \mathrm{NH}_{4}$ in soil treated with control.

Urea hydrolysis did not occur in all the amended soils at the initial days. The perusal data of this investigation reveals that after first, second and third harvesting urease activity increases in manurial treatments as compared to control that might be due to all manurial treatments applied with NPK which rapidly release $\mathrm{NH}_{3}$ and $\mathrm{CO}_{2}$. In all manurial treatment urease activity shows increase activity as days passes. The maximum urease activity was measured after second harvesting, because decomposition of vermicompost, farmyard manure and paddy husk attained 22, 28 and 36 days after incorporation which releases nutrient.

\section{Dehydrogenase activity}

In first sampling the maximum dehydrogenase activity was recorded as $10.7 \mu \mathrm{gTPF} / \mathrm{g}$ in control and minimum activity was observed 9 $\mu \mathrm{gTPF} / \mathrm{g}$ in soil treated with NPK $+1 / 2$ vermicompost $+1 / 2$ farmyard manure. In second sampling the maximum dehydrogenase activity was recorded as $14.86 \mu \mathrm{gTPF} / \mathrm{g}$ in
NPK + paddyhusk and minimum activity was observed $11.05 \mu \mathrm{gTPF} / \mathrm{g}$ in soil treated with NPK + vermicompost. In third sampling the maximum dehydrogenase activity was recorded as $8.8 \mu \mathrm{gTPF} / \mathrm{g}$ in NPK + vermicompost and minimum activity was observed $7.3 \mu \mathrm{gTPF} / \mathrm{g}$ in soil treated with control.

Dehydrogenase enzyme is known to oxidise soil organic matter by transferring protons and electrons from substrate to acceptor. These processes are part of respiration pathways of soil micro-organisms and are closely related to the type of soil and soil air-water conditions (Doelman and Haanstra, 1979; Kandeler et al., 1996; Glinski and Stepniewski, 1985). After second harvesting dehydrogenase activity increases as compared to first and third harvesting in all manurial treatments.

The salient findings of the present study are:

Application of organic manures/amendments in combination with NPK resulted in better growth and biomass of Wheat.

Application of organic soil amendments increases soil total nitrogen and total carbon content as compared to control. Organic manures/ amendment treatment also resulted in soil physical condition that favours better root growth and overall crop production. The results from the decomposition of organic manures/amendments suggest that the 
enzymes like urease, acid and alkaline phosphatase and dehydrogenase in soil increases.

The results from decomposition rate of biological sludge and vermi compost suggest that if applied, should be incorporated in soil well in advance before sowing to enable the plants get nutrient supply from the since day initial stages.

\section{References}

A. A. Safer, S. A. Bizk and A. S. Kl-Sebaay. Effect of Organic Manures on Plant Growth and NPK Uptake by Wheat Egypt.J. Soil Sci. 32 , No, 2.

Abdul mateen, Abdurrab, Fazalmunsif and Kawsarali Effect of cropping patterns, farm yard manure. Sarhad J. Agric. Vol.27, No.3, 2011

Acharya C L, Bishnoi S K, Aduvanshi H S (1988). Effect of long-termapplication of fertilizers and organic and inorganic amendments undercontinuous cropping on soil physical and chemical properties in anAlfisol. Ind. $J$. Agric. Sci. 58:509-516

Ayoub, M., S. Guertin, S. Lussier and D. L. Smith. 1994. Timingand level of nitrogen fertilizer effects on spring wheat yield in eastern Canada. Crop Science. 34:748-756.

Capouchova I, Bicanova E, Petr J, Krejcirova L, Famera O (2008). Effects of organic on wheat cultivation in wider rows on grain yield and quality. Scientia Agriculturae Bohemica 39:

Dormaar J F, Johnston A, Smoliak S (1984). Seasonal changes in carboncontent and dehydrogenase, phosphatase and urease activities in mixedprairie and fescue grassland Ah horizons. J. Range Manag. 37:31-35.
Ghosh, P. K., P. Ramesh, K. K. Bandyopadhyay, A. K. Tripathi, K. M. Hati, A. K. Misra, C. L. and Acharya (2004). Comparative effectiveness of cattle manure, poultry manure, phosphocompost and fertilizer-NPK on three cropping systems in vertisols of semi-arid tropics. I. Crop yields and system performance. Bioresour. Technol. 95:77-83.

Gopinath K A, Saha S, Mina B L, Pande H, Kundu S, Gupta H S (2008) Influence of organic amendments on growth, yield and quality of wheat and on soil properties during transition to organic production. Nutr. Cycl. Agroecosyst 82:

Goyal S, Mishra M M, Hooda I S, Singh R (1992). Organic matter-microbialbiomass, relationships in field experiments under tropical conditions:effects of inorganic fertilization and organic amendments. Soil Biol.Biochem. 24:1081-1084.

Negi, S. C. and M. Gulshan. 2000. Effect of FYM, planting methods and fertilizer levels on rainfed wheat. Crop Res.Hisar. 3(20): 534536.

Paliwal, D. K. Kushwaha, H. S. and Thakur, H. K. 2011. Performance of soybean (Glycine max L.Merrill)-Wheat (Triticum aestivum) cropping system under land configuration, making and nutrient management. Indian Journal of Agronomy,56(4):334-339.

Tabatabai M A, Bremmer J M (1969). Use of Pnitrophenol phosphate forassay of soil phosphatase activity. Soil Biol. Biochem. 1:301-307.

Yadav, A. S. and Arora, Sanjay (2018). Crop residue management in diverse agroecosystems for improving soil health - An overview. Journal of Soil and Water Conservation, India 17(4): 387-392.

Zantua, M. I., Bremner, J. M., 1976. Production and persistence of urease activity in soils. Soil Biol. Biochem. 8, 369-374.

\section{How to cite this article:}

Prerna B. Jetpariya and Sana A. Kalyani. 2021. Effect of Organic Manures on the Growth of Wheat (Triticum aestivum) and Soil Enzymatic Activity. Int.J.Curr.Microbiol.App.Sci. 10(07): 671-680. doi: https://doi.org/10.20546/ijcmas.2021.1007.073 